\title{
ENGLISH JUDGMENTS IN FOREIGN CURRENCY: A "PROCEDURAL" REVOLUTION
}

\author{
J.H.C. MORRIS*
}

Prior to 1975 it had been regarded as settled law for at least 350 years that an English court could not give judgment for the payment of an amount expressed in foreign currency." The reason for this rule was that the sheriff could not be expected to know the value of foreign currency and thus could not enforce any judgment by execution unless it was expressed in pounds sterling. The rule was re-asserted by the Court of Appeal in $1898^{2}$ and by an unanimous House of Lords in $1960 .^{3}$ But in 1975 , after a chapter of accidents in the Court of Appeal, the House of Lords overruled its own previous decision and held that judgment could be given for an amount expressed in foreign currency "or the sterling equivalent thereof at the date when the court authorises enforcement of the judgment in terms of sterling." It is the object of this paper to explain how this traumatic event came about.

Given the existence of the rule that English judgments cannot be expressed in foreign currency, it is obvious that there must be subsidiary rules laying down at what date damages or debts expressed in foreign currency must be converted into sterling for purposes of an English judgment. It is at first sight surprising that these subsidiary rules did not become articulate until just after the first world war. The explanation is, of course, that in the nineteenth century and until 1914 the currencies of the major trading nations of the world remained relatively stable in relation to each other, and so the problems did not arise.

A convenient starting-point is the decision of the House of Lords in S.S. Celia \%. S.S. Volturno. ${ }^{5}$ A collision occurred in the Mediterranean in December

* D.C.L., F.B.A.; Honorary Fellow of Magdalen College, Oxford; Emeritus Reader in Conflict of Laws in the University of Oxford.

1. Two early cases frequently cited for this proposition are Rastell v. Draper, 80 Eng. Rep. 55 (K.B. 1605) and Ward v. Kidswinn, 82 Eng. Rep. 283 (K.B. 1626). The report of the latter case is in Norman-French, but is conveniently translated by Lord Simonds in In re United Rys. of the Havana \& Regla Warehouses Ltd., [1961] A.C. 1007, 1044. Other cases from the 16th and 17th centuries are cited by Lord Wilberforce in Miliangos v. George Frank (Textiles) L.d., [1976] A.C. 443,466 .

2. Manners v. Pearson \& Son, [1898] l Ch. 581.

3. In re United Rys. of the Havana \& Regla Warehouses Ltd., [1961] A.C. 1007

4. Miliangos v. George Frank (Textiles) Ltd., [1976] A.C. 443, 468; for an American discussion, see Becker, The Currency of Judgment, 25 Ам. J. CoмP. L. 152 (1977).

5. [1921] 2 A.C. 544 . 
1917 between a British and an Italian ship, due mainly to the negligence of the master and crew of the former. The Italian ship was repaired temporarily at Gibraltar and permanently at Newport News, Virginia. During the periods of the repairs the owners of the Italian ship lost an amount by way of hire which would have been paid by the Italian Government. Their total claim in respect of these repairs and losses was for 304,418 lire. Before the hearing the lira depreciated in relation to the pound sterling. The House of Lords (Lord Carson dissenting) held that the claim must be converted into sterling at the rate of exchange prevailing when each item of loss or damage was incurred.

In the previous year the Court of Appeal had held in Di Ferdinando $v$. Simon, Smits $\mathcal{E}^{2}$ Co. ${ }^{6}$ that damages for breach of contract must be converted into sterling at the rate of exchange prevailing on the day of breach, notwithstanding a $50 \%$ depreciation of the lira (the money of account) between that day and the day of judgment. These two cases settled the English law as to the conversion date for damages for tort and for breach of contract respectively. At first sight they seem discrepant, since in the Volturno case the date chosen was the date when the items of loss or damage were incurred, while in the Di Ferdinando case it was the date of the breach. But in that case the claim was for non-delivery of goods under a contract of carriage, so that the date of breach and the date for assessing the damages were the same. Had the claim been for consequential loss suffered at a date later than the date of breach, that later date might well have been selected as the date for conversion.

Though the law was thus settled for claims for damages for tort and for breach of contract, doubts remained for another 40 years as to what should be the conversion date in claims for a liquidated debt. These doubts persisted largely because of two decisions of the Court of Appeal which appeared to be inconsistent, or at least difficult to reconcile: Société des Hotels Le Touquet Paris-Plage $\%$. Cummings ${ }^{7}$ and Madeleine Vionnet et Cie. $v$. Wills. ${ }^{8}$ In both cases the plaintiff was a French company, the defendant was an Englishwoman, the debt was expressed in French francs, and French francs depreciated in terms of sterling between the date when the debt became due and the date of the hearing. In the Cummings case the defendant paid the amount of the debt in French francs to the plaintiff's manager after the issue of the writ and before the hearing. It was held that she had discharged her debt and that no further payment was due from her for the difference in sterling value between the amount of the debt in French francs in 1914 (when the debt was payable) and 1921 (when the case was heard). The inference is that had she not paid the debt, the conversion date would have been held to be the date of judgment. ${ }^{9}$

6. [1920] 3 K.B. 409 .

7. [1922] 1 K.B. 451 .

8. $[1940]$ I K.B. 72.

9. See especially [1922] 1 K.B. 451,465 (per Atkin, L.J.). 
However, in the Wills case the defendant paid into court, after the issue of the writ, the sterling equivalent of the debt at the date of payment; and this time it was held that she remained liable to pay the difference between this sterling sum and the sterling equivalent of the amount of the debt at the time when it was due. The inference is that had she not made any payment into court, the conversion date would have been held to be the date when the debt became payable.

In Cummings $v$. London Bullion Co. ${ }^{10}$ it was argued that these two decisions were inconsistent and that the Court of Appeal was therefore entitled to choose between them; but the court preferred to rest its decision on another ground. The plaintiff, an American tourist temporarily in England, bought a platinum brooch from the defendant as a present for his wife for $\$ 3200$. It was agreed that if the wife did not like the brooch, the plaintiff could return it and get his money back. The wife did not like the brooch, so on August 15th 1949 the plaintiff returned it and departed to the United States. Under the Exchange Control Act 1947, the defendant needed Treasury consent before he could lawfully refund the price in dollars to the plaintiff in America. Such consent was not asked for until September 20th and not granted until September 29th. Meanwhile on September 18th the pound was devalued from $\$ 4.02$ to $\$ 2.80$ and the equivalent of $\$ 3200$ consequently rose from $£ 796$ to $f 1,142$. It was held that the defendant was liable to refund the larger sum, because the debt was not payable until Treasury consent was obtained. Thus a grave injustice was averted by means of a technicality.

In In re United Railways of the Havana and Regla Warehouses Ltd. " the House of Lords re-asserted the rule that English courts cannot give judgment for an amount expressed in foreign currency and also decided unanimously that in claims for a liquidated debt the date for conversion into sterling is the date when the debt is payable. Lord Simonds (astonishingly) regarded as "extremely enlightening if not decisive"12 the fact that in the 17 th century the form of action for the recovery of a foreign debt was not debt but detinet. (Fancy allowing differences between the forms of action-“"archaic legalistic nonsense"13 buried in 1852-to decide an important question of principle over a century later!) But he was also understandably influenced, ${ }^{14}$ as was Lord Radcliffe, ${ }^{15}$ by the inelegance that would have resulted from having two different dates for conversion, one for liquidated debts and the other for unliquidated damages. Lord Denning began his discussion of the problem

\footnotetext{
10. [1952] I K.B. 327.

11. [1961] A.C. 1007 .

12. Id. at 1043 .

13. Schorsch Meier G.m.b.H. v. Hennin, [1975] Q.B. 416, 430 (per Lawton, L.J.).

14. [1961] A.C. $1007,1049$.

15. Id. at 1060 .
} 
with the emphatic statement: "If there is one thing clear in our law, it is that the claim must be made in sterling and the judgment given in sterling. We do not give judgments in dollars any more than the United States courts give judgments in sterling." 16

This case seemed to have settled the English law once and for all, for good or for ill. But nothing is settled law nowadays, not even when it is laid down in a recent and unanimous decision of the House of Lords.

It can scarcely be doubted that the rule thus laid down was an unjust rule, because it made an anomalous and unnecessary exception to the principle of nominalism, which "of all the principles which govern the treatment of money obligations in this country ... . is the most fundamental."17 If a debt is expressed in foreign currency, both parties expect to measure their rights and obligations in terms of that currency and no other. The creditor should bear the risk of a depreciation of that currency after the date of maturity of the debt; the debtor should bear the risk of its appreciation. Yet if the creditor can (or must) bring his action in England, e.g. because the debtor is resident there or is not resident anywhere else, it may be just the other way round, because the debt has to be converted into sterling at the rate of exchange prevailing on the date when it became payable. Hence, if the foreign currency depreciates in terms of sterling after that date, the creditor recovers more than the debtor promised to pay, while if it appreciates, he recovers less.

In federal courts in the United States (except in diversity cases), a better rule was laid down by a bare majority of the Supreme Court in Die Deutsche Bank Filiale Nurnberg $v$. Humphrey. ${ }^{18}$ The rule of that case is that if the debt is expressed in foreign currency, and is payable abroad, it must be converted into dollars at the rate of exchange prevailing on the day of judgment. The rule is better than the English rule because, if the foreign currency is appreciating, the creditor does not suffer so big a loss. But it is far from ideal because, owing perhaps to a series of appeals, a considerable interval may still elapse between the date of judgment and the date of execution or payment. In his opinion in this case, Holmes J. cited Soriété des Hotels Le Touquet ParisPlage $\%$. Cummings ${ }^{19}$ thereby suggesting that he thought it consistent with the judgment-day rule he was laying down. At the end of his opinion he made an uncharacteristic slip, ${ }^{20}$ referring inadvertently not to the day of judgment but to "the moment when the suit is brought"-and this has misled some ${ }^{21}$ but

\footnotetext{
16. Id. at 1068-69.

17. A. Dicey \& J. Morris, Conflict of Laws 878 (9th ed. 1973) (Professor Kahn-Freund).

18. 272 U.S. 517 (1926).

19. [1922] 1 K.B. 451 , ciled in 272 U.S. at 519.

20. That it was a slip is clear from Reissner v. Rogers, 276 F.2d 506, 511 (D.C. Cir. 1960) and cases there cited.

21. In re United Rys. of the Havana \& Regla Warehouses Ltd., [1961] A.C. 1007 (per Lord
} 
not all ${ }^{22}$ English judges as to what the case decided.

The courts of some states, notably New York, still continued to prefer the breach-date rule: ${ }^{23}$ and federal courts sitting in those states are of course required by Erie Railroad Co. $\%$. Tompkins ${ }^{24}$ to apply that rule in diversity of citizenship cases. ${ }^{25}$ Lord Denning quoted the New York rule in the United Railways case, ${ }^{26}$ and remarked that it was better suited to a commercial community.

Although the injustices and anomalies of the breach-date rule were forcefully pointed out by English writers, most notably by Dr. F.A. Mann ${ }^{27}$ and Professor O. Kahn-Freund, ${ }^{28}$ it was not until sterling depreciated in terms of the foreign currency (rather than the other way round, as in the earlier cases) that English judges began to be aware of the defects of the rule. Lord Denning's conversion, which has had such a dramatic effect on the development of the law, came about in The Teh $\mathrm{Hu},{ }^{29}$ a salvage case decided by the Court of Appeal in 1970. The facts were sufficiently striking. An explosion occurred in the engine room of a Panamanian ship in mid-Pacific. At the request of the owners, a Japanese salvage tug came to the rescue and towed the half-waterlogged ship 2000 miles to Honolulu. Before the towage started the master of the tug and the master of the ship signed a salvage agreement in Lloyds' standard form which provided for arbitration in London. The owners of the ship kept their accounts in United States dollars; the salvors in Japanese yen. The salvage services were rendered in February 1967; the pound was devalued in November 1967; the appeal arbitrator made his final award in 1969, awarding the salvors $£ 50,000$ on the basis that it was proper to take the devaluation of the pound into account. But Brandon J. and the majority of the Court of Appeal (Lord Denning M.R. dissenting) held that only $£ 45,000$ was payable, because the United States dollars or Japanese yen had to be converted into sterling at the date when the salvage services terminated in February 1967. Lord Denning's approach to the problem was somewhat different from what it had been in the United Railways case only ten years before. In that case the breach-date rule was "the one thing clear in our law;" but in

Simonds at 1048); (per Lord Reid at 1052); The Teh Hu, [1970] P. 106, 128 (per Salmon, L.J.); Miliangos v. George Frank (Textiles) Ltd., [1976] A.C. 443, 483 (per Lord Simon of Glaisdale.)

22. In re Hawkins, [1972] Ch. 714, 721 (per Megarry, V.C.); Miliangos v. George Frank (Textiles) Ltd., [1976] A.C. 443, 469 (per Lord Wilberforce).

23. See Restatement (Second) of Conflict of Laws \$ 144, Reporter's Note (1971); Libraire Hachette, S.A. v. Paris Book Center, Inc., 309 N.Y.S.2d 701 (Sup. Ct. 1970); Becker, supra note 4; F. ManN, Legal Aspect of Money 358 n.2 (3d ed. 1971).

24. 304 U.S. 64 (1938).

25. Compagnia Engraw Commercial E. Indus. S.A. v. Schenley Distillers Corp., 181 F.2d 876, 879 (9th Cir. 1950).

26. [1961] A.C. 1007,1070 .

27. F. MANN, supra note 23 , at 361-76.

28. A. DICEY \& J. Morris, supra note 17 , at $882-83$, 909-13

29. [1970] P. 106. 
this case Lord Denning ended his judgment as follows: ${ }^{30}$

So the arbitrator did what was just. But the judge felt compelled to overthrow his award. In the name of the law, the judge has denied justice to the parties. He realised that by so doing he might imperil the "international acceptability of Lloyd's standard form": but he thought the danger could be removed by an appropriate amendment of the form. I fear he may be too optimistic. Lloyd's form has hitherto been internationally acceptable because men of all nations have been confident they could get justice in London at the hands of English arbitrators. But once justice is denied, confidence is lost. And once confidence is lost, it is hard to restore. I would not myself expose Lloyd's form to the risk. I would do herein what is just and not what is unjust. I would allow the appeal.

To this thunderbolt, the majority could only reply (rather feebly), "I cannot agree that the confidence of foreign salvors and owners in the justice administered by our courts can be shaken by the fact that in this particular case the decision of the court is in accordance with the established rule of English law."31 "Having regard to the agreement reached between the parties, I am unable to accept that the judgment appealed from has denied them justice." 32

The Teh $\mathrm{Hu}$ came before the courts by way of case stated by the arbitrator; and the judgments of the Court of Appeal contain conflicting dicta on a point which had never been decided, namely, whether an English arbitrator could express his award in a foreign currency. Lord Denning said that he could; ${ }^{33}$ Salmon L.J. said that he could not. ${ }^{34}$ This point arose for direct decision in Jugoslavenska Oceanska Plovidba v. Castle Investment Co., Inc. ${ }^{35}$ Jugoslav shipowners chartered a ship to a Panamanian company. The charterparty contained a London arbitration clause. The money of account was United States dollars. A dispute arose as to the amount of hire payable to the owners. After the devaluation of sterling, it was held by the Court of Appeal (Lord Denning M.R., Cairns and Roskill L.JJ.) not only that the arbitrators could make their award in United States dollars, but also that the award could be enforced "in the same manner as a judgment" under section 26 of the Arbitration Act 1950, that is, without the plaintiffs having to bring an action on the award at common law. All three judges pointed out how anomalous it would be if a foreign award (which would probably be expressed in foreign currency) could be summarily enforced (under section 36 of the Act), but a domestic award expressed in foreign currency could not. ${ }^{36}$ Roskill L.J. regarded the rule that judgments must be for an amount expressed in sterling as "now established

30. Id. at $126-27$.

31. Id. at 132 (per Salmon, L.J.).

32. Id. at 135 (per Karminski, L.J.).

33. Id. at $124-26$.

34. $I d$. at 129.

35. [1974] Q.B. 292.

36. Id. at $300,301,305$. 
beyond judicial challenge, however much one may regret it." ${ }^{37}$ But Lord Denning was not so sure: he thought that the rule was open to reconsideration; but he conceded that "this is not yet the law." 38

The plot now begins to thicken with a vengeance. The opportunity for reconsidering the rule for judgments came unexpectedly in the very next year. In Schorsch Meier G.m.b.H. v. Hennin, ${ }^{39}$ German sellers sold goods to an English buyer for a price expressed in Deutschmarks. The sterling equivalent was $£ 452$ when the debt became due in February 1972 and (after a fall in the value of the pound) $£ 641$ in July 1975 when the German seller issued his writ. As in the Jugoslavenska case, the defendant did not appear and was not represented. The Court of Appeal (Lord Denning M.R., Lawton L.J. and Foster $J$.), reversing the county court judge, held that the court could give judgment for the amount of the price in Deutschmarks "or the sterling equivalent thereof at the date when the court authorises enforcement of the judgment in terms of sterling." Two reasons were given for this remarkable decision. The first reason was that article 106 of the Treaty of Rome (establishing the European Economic Community) provides that:

Each Member State undertakes to authorise, in the currency of the Member State in which the creditor or beneficiary resides, any payments connected with the movement of goods, services or capital, and any transfers of capital and earnings, to the extent that the movement of goods, services, capital and persons between Member States has been liberalised pursuant to this Treaty.

The second reason for the decision (from which Lawton L.J. dissented) was that the court was not bound to follow the United Railways case because cessante ratione legis cessat ipsa lex (when the reason for a rule of law ceases to exist, the rule ceases to bind). Of these two reasons for distinguishing or declining to follow the United Railways case, it is enough to say that the House of Lords in Miliangos \%. George Frank (Textiles) Ltd. ${ }^{40}$ regarded both as totally inadequate.

The next and most important case is the Miliangos case, which also was an action against an English buyer for the price of goods sold; but this time the seller was a Swiss, so the Treaty of Rome point was not available, Switzerland being outside the European Economic Community. The price was quoted in Swiss francs and Swiss law was the proper law of the contract. The sterling equivalent of the price was $£ 42,000$ in 1971 when payment was due and $£ 60,000$ in 1974 at the date of the hearing. The writ was issued in 1972. The buyer counter-claimed for damages for breach of warranty as to quality. In November 1974 the buyer abandoned his defense and counterclaim. A few days later, after the Schorsch Meier case was decided, the Swiss seller asked for

37. Id. at 303 .

38. Id. at 299.

39. [1975] Q.B. 416.

40. [1976] A.C. 443, 465, 471-77, 497, 498, 501, 503. 
and obtained leave to amend his statement of claim so as to ask for judgment in Swiss francs. The first ratio of the Schorsch Meier case was irrelevant because Switzerland is not a member of the E.E.C. The second ratio placed the trial judge (Bristow J.) in something of a dilemma. On the one hand there was the unanimous decision of the House of Lords in the United Railways case which clearly precluded him from giving judgment in Swiss francs or from awarding the sterling equivalent of the price converted at any other date than the date when the price was due. On the other hand there was the majority decision of the Court of Appeal in Schorsch Meier which had declined to apply the United Railways decision. In these embarrassing circumstances, Bristow J. held that the second reason for the decision in Schorsch Meier must have been given per incuriam; and he gave judgment for the sterling equivalent of the price at the date when it was due, i.e. $£ 42,000$. He remarked: ${ }^{41}$

I am faced with a judgment of a majority of the Court of Appeal, which in its application to the issue raised before me says that a rule of English law taken for granted by the Court of Appeal and the House of Lords for some 350 years is no longer a rule of English law.

Predictably, the seller appealed to the Court of Appeal, and predictably that court (consisting of Lord Denning M.R., Stephenson and Lane L.JJ.) held that its second ratio in Schorsch Meier had not been given per incuriam, reversed the decision of Bristow $\mathrm{J}$. and gave judgment for the price in Swiss francs in the same form as in Schorsch Meier. An appeal was taken to the House of Lords, where Lord Wilberforce observed that "some distortion in the judicial process has been brought about." ${ }^{42}$ But in the end the House of Lords (Lord Simon of Glaisdale dissenting) dismissed the appeal, while castigating Lord Denning's refusal to bow to the authority of the United Railways case. Two members of the majority (Lord Wilberforce and Lord Cross of Chelsea $)^{43}$ were deeply impressed by the importance of not overruling the Jugoslavenska case, which would have been the inevitable consequence of allowing the appeal. That would have dealt a serious blow to the City of London as a centre for international arbitration, and might even have had repercussions on the balance of payments.

It is impossible to do justice here to Lord Simon of Glaisdale's lengthy dissenting judgment, but a few trenchant sentences may perhaps give the flavour of it: ${ }^{44}$

First, I do not think that this is a 'law reform' which should or can properly be imposed by judges; it is, on the contrary, essentially a decision which demands a far wider range of review than is available to courts following our traditional and valuable adversary system-the sort of review compassed by an

41. [1975] Q.B. 487, 492 .

42. [1976] A.C. $443,459$.

43. $I d$. at $464,497$.

44. Id at $480-81$. 
interdepartmental committee. Secondly, your Lordships' predecessors have wisely set limits on the use of the power to overrule previous decisions of your Lordships' House; and no sufficient reason has, in my view, been shown for overruling the [United Railways] decision. ...

The instant appeal raises questions the answer to which imperatively demands the contribution of expertise from far outside the law-on monetary theory, public finance, international finance, commerce, industry, economics -for which judges have no training and no special qualification merely by their aptitude for judicial office. All such experience as I have had of decision-making within and without the law convinces me that the resolution of this issue demands a far greater range of advice and a far more generally based knowledge than is available to a court of law-even one assisted, as we have been, by the most meticulous, cogent and profound argument of counsel. Law is too serious a matter to be left exclusively to judges.

One cannot leave this case without reflecting how much the development of the law depends on the accidents of litigation. Had the three cases of Jugoslavenska, Schorsch Meier and Miliangos come before the courts in the reverse order, the decision in Miliangos might well have gone the other way, because of course the Treaty of Rome point was not available, and the Jugoslavenska case would have been still below the horizon. In that event, even Lord Denning might have hesitated before distinguishing Miliangos in Schorsch Meier because of the Treaty of Rome point. And in that event it seems highly probable that the Jugoslavenska case would also have gone the other way.

As a precedent, the decision in the Miliangos case was expressly confined to claims for a liquidated debt expressed in foreign currency in cases where the proper law of the contract is that of a foreign country and where the money of account and of payment is that of that country or possibly of some third country outside the United Kingdom. ${ }^{45}$ The House of Lords expressly declined to review the whole field of the law regarding foreign currency obligations, leaving it open to future discussion whether the same rule should apply to claims for damages for tort or breach of contract. It has subsequently been held that the court can give judgment for an amount in foreign currency as damages for breach of contract ${ }^{46}$ or for tort. ${ }^{47}$ It has also been held that the principle of Miliangos applies even though the proper law of the contract is English law. ${ }^{48}$ This is in accordance with principle, because the rule of Miliangos (like its predecessor, now overruled) is a rule of the English law of procedure, and therefore the proper law of the contract, the place of payment or (in a tort case) the place of tort should all be irrelevant.

45. Id. at $467-68,497-98,503$.

46. Jean Kraut A.G. v. Albany Fabrics Lıd., [1977] 1 Q.B. 182; Services Europe Atlantique Sud (SEAS) v. Stockholms Rederiaktiebolag Svea, [1977] 3 W.L.R. 176 (Q.B.).

47. The Despina R., The Times, Feb. 2, 1977. [1977] 3 W.L.R. 597 (C.A.).

48. Services Europe Atlantique Sud v. Stockholms Rederiaktiebolag Svea, [1977] 3 W.L.R. 176 (Q.B.); Barclays Bank Int'l Ltd. v. Levin Bros. (Bradford) Ltd., [1977] Q.B. 270; Federal Commerce \& Navigation Co. Ltd. v. Tradax Export S.A., [1977] Q.B. 324, 341-42, 349, 354 (C.A.), rev'd on other grounds, [1977] 3 W.L.R. 126 (H.L.). 
In Miliangos the majority of the House of Lords adopted the formula that had been devised by Lord Denning in the Schorsch Meier case, namely, that if the plaintiff claims an amount in foreign currency, judgment may be given for that sum or the sterling equivalent at the time of payment, i.e. the date when the court authorizes enforcement of the judgment in terms of sterling. ${ }^{49}$ As Lord Wilberforce put it, "This date gets nearest to securing to the creditor exactly what he bargained for." ${ }^{50}$ It is therefore a preferable solution to the judgment-date rule laid down by the majority of the Supreme Court of the United States in Die Deutsche Bank Filiale Nurnberg v. Humphrey. ${ }^{51}$

49. [1976] A.C. $443,463,468,497-98,501$.

50. Id. at 469 .

51. Compare the text of a provision appearing in the Draft Convention initialled October 26 , 1976 between the United Kingdom and the United States providing for the Reciprocal Recognition and Enforcement of Judgments in Civil Matters, Cmnd. 6771 (1977), I6 INT'L LEGAL Materials 71 (1977), art. 17(5): "Money judgments entitled to enforcement under the Convention may be enforced by the court addressed either in the currency specified in the judgment or in the local currency at the buying rate in the place where and on the date when enforcement is granted under paragraph (1) of Article 16 or registration for enforcement is effected under paragraph (2) of Article 16." 